ЈЕЛЕНА Љ. МИНИЋ ${ }^{1}$

УНИВЕРЗИТЕТ У ПРИШТИНИ СА ПРИВРЕМЕНИМ СЕДИШТЕМ

У КОСОВСКОЈ МИТРОВИЦИ, ФИЛОЗОФСКИ ФАКУЛТЕТ

КАТЕДРА ЗА ПСИХОЛОГИЈУ

\title{
ТАНАТОС - НАГОН СМРТИ
}

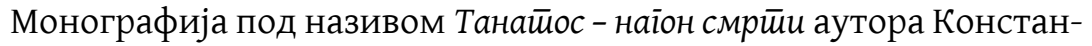
тина Момировића, Петра Костића и Анкице Хошек већ самим својим називом интригира и позива на читање, проучавање и размишљање о вечитој теми смрти и нагона за уништењем, разарањем и повређивањем себе и других. Аутори монографије у основи се баве агресивним понашањем (убилачким - хетероагресијом и самоубилачким - аутоагресијом) као друштвеном појавом која привлачи пажњу великог броја научника, истраживача, наставника, родитеља итд., управо због све веће учесталости, нарочито међу млађом (омладинском) популацијом. Како сами аутори наводе, монографија је написана са основним циљем да се њени резултати (ис)користе ради превенције насиља у нашој средини. Нарочито је истакнут значај превентивног рада са младима како би се негативне и веома сложене последице насиља спречиле и/или ублажиле. Аутори истичу да се добијени резултати истраживања и изведени закључци који су изнесени у монографији могу искористити не само за потребе превенције и неопходних превентивних мера већ и за селекцију људи и то у оним подручјима у којима је агресивност значајан фактор ризика (као што је војска, полиција и слично). Такође, аутори у монографији истичу да предложене технике мерења агресивности треба даље усавршавати, како би се повећала могућност њихове

jelena.minic@pr.ac.rs

Приказ је примљен 23. септембра 2019, а прихваћен за објављивање на састанку Редакције Зठорника одржаном 3. децембра 2019. 
примене у превентивном и прогностичком смислу, нарочито када је насилништво код младих у питању.

На самом почетку монографије видљива је систематичност и јасност идеје водиље, истакнуте у формулисању пет основних истраживачких питања које аутори на страницама монографије детаљно научно и методолошки обрађују, долазећи до емпиријских потврда почетних хипотеза и недвосмислених одговора на постављена питања с почетка монографије. Наиме, питања које аутори Константин Момировић, Петар Костић и Анкица Хошек постављају су: 1. Како ће власти земаља спроводити превенцију младалачке насилности ако нема препознавања насилника у школама? 2. Да ли постоји економичан начин да се препозна 3 до 5 \% младих насилника у нашој средини? 3. Како препознати болесне насилнике пре него што симптоми њихове болести постану ужасна стварност? 4. Има ли начина да се потенцијал зла мери пре него што постане остварен? 5. Могу ли се тестовима детектовати особе подложне ауторитетима и спремне да за ауторитете учине све?

Издавач монографије је Центар за примењену психологију из Београда. Монографија је издата 2007. године, а има укупно 140 страна. Поред Предговора, Закључне дискусије, Литературе (155 коришћених референци) и Прилога (Скале убилачке и самоубилачке модулације нагона смрти, Описа личности испитаника намењен њему самом и Описа личности испитаника намењен психологу) монографија има и пет суштинских делова (поглавља), који у ствари представљају 5 научних радова који имају за циљ да одговоре на постављена истраживачка питања представљена у Предговору аутора. Поменути делови, тј. поглавља у монографији представљени су под следећим називима: 1. Наїон смрӣu:Генеза

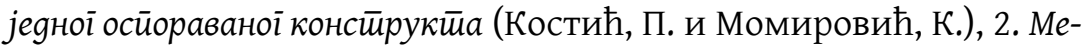

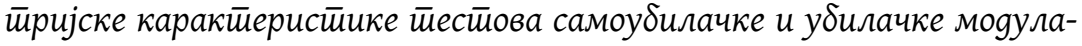

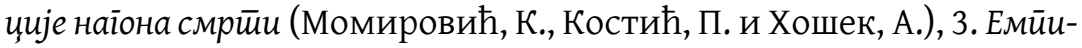
ријски докази о еізистенцији и заједничко језіро самоубилачке и убилачке моgулације наїона смрӣи (Хошек, А., Момировић, К. и Костић, П.), 4. Релације убилачке и самоубилачке модулације наїона смрӣи

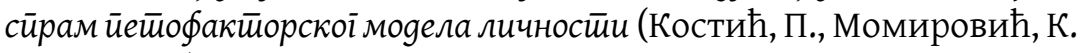
и Хошек, А.) и 5. Тесйовне норме самоубилачке и убилачке моgулације наїона смрйи (Момировић, К., Костић, П. и Хошек, А.).

У делу монографије - Наїон смрӣu: Генеза јеgної осӣораваної кон-

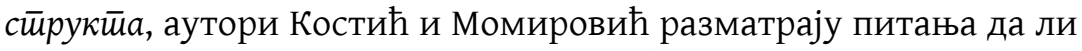
је агресија мотив, нагон или нешто треће или и једно и друго, за- 
тим се ठаве генезом нагона смрти у Фројдовом делу, као и другим облицима агресивног понашања изведених из Фројдове теорије. Такође, аутори се ठаве и генезом агресивности и нагона смрти и у делима осталих психоаналитичара, уз посебно истицање питања ко, како и зашто прихвата агресивност, а оспорава Танатос. Аутори се у овом поглављу монографије ठаве и биологијом агресивности, као и нормалним и патолошким у агресији. Аутори завршавају ово поглавље износећи одређене хипотетичке закључке од који се издвајају следећи: „извесни нивои агресивности у сваком од нас су услов биолошког опстанка и сви правци психологије и сви значајни психолози, психијатри, социолози и филозофи имају понешто да кажу о људској агресивности“ (стр. 44).

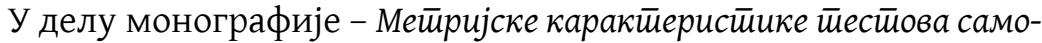
убилачке и убилачке моgулације наїона смрйи, аутори Момировић, Костић и Хошек разматрају, како и са назив каже, метријске карактеристике скале самоубилачке и убилачке модулације нагона смрти. Узорак испитаника у овом истраживању су чинили војници (Н=531) старости од 19 до 27 година. Аутори закључују да је „психометријски изводљиво операционализовати обе модулације нагона смрти“ (стр. 57). Скала самоубилачке модулације нагона смрти (скр. ССТ) показала је убедљиве метријске карактеристике у погледу репрезентативности и поузданости, а Скала убилачке модулације нагона смрти (скр. СУТ) у погледу дискриминативности и информативности. Аутори закључују да су метријске карактеристике обе скале и Скале убилачке и самоубилачке модулације нагона смрти задовољавајуће и да омогућавају њихову примену у професионалној пракси.

У делу монографије - Емӣиријски gокази о еїистеенцији и зајеg-

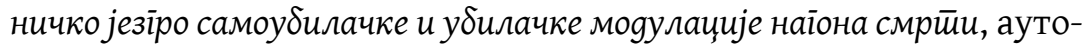
ри Хошек, Момировић и Костић износе доказе да постоји заједничко језгро и тесна повезаност обе модулације нагона смрти и да су самоубилачке тенденције доминантније од убилачких. Аутори долазе до ових закључака кроз истраживање које је спроведено на узорку од 567 испитаника мушког пола, старости од 19 до 27 година. Добијене резултате тумаче на следећи начин: убилачке и самоубилачке модулације су „манифестне варијабле једне исте, латентне, коју оличава нагон смрти“ (стр. 64). Доминантност самоубилачких тенденција у односу на убилачке аутори објашњавају унутрашњом потребом људских ठића за самоуниште- 
њем, док је уништење другог „пука замена детерминисана снагом жеље за сопственим самоодржањем“ (стр. 65).

У делу монографије - Релације убилачке и самоубилачке моgула-

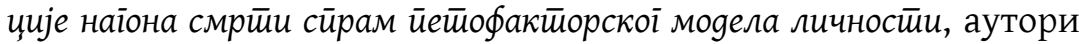
Костић, Момировић и Хошек баве се везама убилачких и самоуठилачких модулација нагона смрти са димензијама личности „Великих пет“. Истраживање је спроведено на узорку од 608 испитаника, 400 испитаника мушког пола и 208 испитаника женског пола. Закључак истраживања је да постоје високи ефекти структуре личности на агресивно понашање и да је „агресивно понашање, операционализовано Фројдовим конструктом нагона смрти, тако чврсто уткано у структуру личности његових актера“ (стр. 86). Такође, аутори закључују да се добијени резултати могу искористити за прогнозу нивоа модалитета нагона смрти и то у истраживаче, али и практичне сврхе, као што су превенција и селекција.

У делу монографије - Тесӣовне норме самоубилачке и убилачке

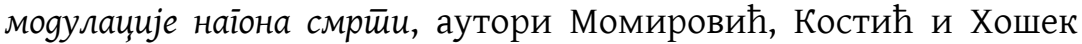
ठаве се нормирањем, тј. одређивањем тестовних норми или баждарењем скала самоубилачке и убилачке модулације нагона смрти. У овом делу су, између осталог, дате, тј. приказане табеле норми према полу за убилачке и самоубилачке модулације нагона смрти, као и полне разлике у доменима и аспектима личности између мушкараца и жена.

Кроз наведене делове монографије аутори су одговорили јасно, систематично и емпиријски на постављена истраживачка питања с почетка монографије. Наиме, аутори закључују да се мерењем могу препознати насилници у америчким и француским школама (узети су подаци АФТ-а, тј. Америчког савеза наставника и њиховог извештаја о насиљу и последицама насиља), да се може идентификовати 3 до 5\% младих насилника у нашој средини, затим да се могу открити или разоткрити зли насилници. Такође, оно што је, чини се важно, јесу и одговори да се потенцијал насилништва може мерити и да постоје одрећени знаци којима се могу препознати особе које су до те мере подложне утицају ауторитета да су спремне крајње некритички да учине све оно што ауторитети од њих захтевају.

На самом крају, аутори монографије Константин Момировић, Петар Костић и Анкица Хошек закључују да је агресија наслеђен, ठиолошки детерминисан и укорењен потенцијал сваког појединца, који обликује, усмерава, моделира, појачава или снижава сре- 
дина у којој појединац одраста и живи. Аутори завршавају своју монографију следећом реченицом: „људска деструкција је зло ठез кога човечанство не може, али може научити да живи с њом, да је мери, контролише и каналише тако да оптимализује баланс штете и користи од ње“ (стр. 123). Читалац ове монографије управо може стећи утисак да су њени аутори учинили важан корак у мерењу људске деструкције, који значајно може да помогне да се она контролише и каналише са циљем њене оптимализације и добробити свих нас.

Написано у тексту изнад је само кратак приказ монографије

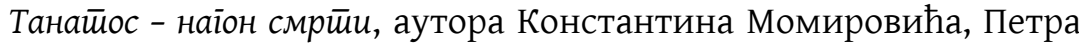
Костића и Анкице Хошек, која нуди прегршт информација, научних чињеница, емпиријских доказа, предлога и решења како се на личном и друштвеном нивоу борити са Танатосом (нагоном смрти), који је верни пратилац Ероса (нагона живота) код сваког од нас. Аутори нуде одговоре на ठројна питања агресије и аутоагресије и подстичу на размишљање шта као појединци и друштво можемо учинити како бисмо их мерили, пре свега, а онда контролисали и каналисали.

Овај чланак је објављен и дистрибуира се под лиценцом Creative Commons Ауторство-Некомерцијално Међународна 4.0 (CC BY-NC 4.0 |

https://creativecommons.org/licenses/by-nc/4.0/).

This paper is published and distributed under the terms and conditions of the Creative Commons Attribution-NonCommercial International 4.0 licence (CC BY-NC 4.0 | https://creativecommons.org/licenses/by-nc/4.0/). 